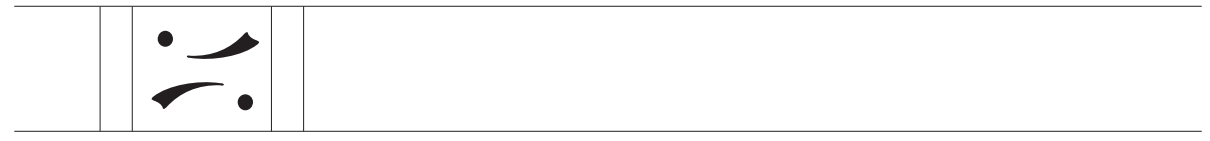

\title{
11 Students Re-Discovering the University: Presence of Mind and Body
}

\author{
Jan Masschelein \\ KU LEUVEN \\ MaArten Simons \\ KU LEUVEN
}

Abstract: The article starts from the observation of a rediscovery and reoccupation of the university that continues the history of smaller or bigger revolutionary movements establishing a universitas studii. The thesis is, first, that today's de-identification with screen work and the affirmation of the importance of places to study is about the willingness to realize a public and collective presence of mind. Second, we elaborate on the thesis that students today perhaps are not rediscovering on campus education in order to fulfill their need for social life or social contact, but to answer the call of the university and its promise of a meaningful, contestable, experimental encounter with "something" that makes them study. Students as well as professors seem to prefer to be where something happens and as it happens, despite the streaming or recordings being available. Today's mediation by the screen transforms the lecture, seminar, or discussion into an image, which makes the student an outsider or spectator. Studying seems to not only involve a presence of mind but a simultaneous presence of body.

Keywords: university, screen, body, on campus, COVID-19, pedagogy

It is already for years now-in fact, since the screen and online activities started to pervade their work - that students at Leuven University increasingly and 
massively "occupy" the (silent) reading rooms of libraries. This occupation is less about having access to books and archives as it is about studying; particularly studying alone while being together. ${ }^{1}$ This "movement" led our university also to build new physical spaces that allow for studying together (and alone). These spaces are known at many universities as "learning centers." This indicates at least that "homework" does not "naturally" offer the right conditions for (all forms of) study despite the student becoming "independent" from time-space restrictions due to the personal computer, the 24/7 Internet, the availability everywhere and anytime, the social media, etc. In some countries, this movement of leaving home to study was accompanied by the increasing success of coffee shops as places to study. Moreover, the pandemic we live(d) in 2020-2021 revealed a strong, and unexpected, longing for "on campus" education. Not only to have more close social contact in times of social distancing, but also to partake in physical, embodied lectures, and seminars. As if the pandemic made students (re)discover the university. The university, not as an abstract idea, but as a place that allows for a particular form of study. It is as if students are declaring today: "We are not just screen-workers or independent learners in need of social platforms. We are students partaking in collective public - not social-gatherings."

In contrast to the stories about the end of the university, we think that these declarations suggest that university study is not only finding place again, but also taking its place again. We contend that the physical "occupation" of the university, the creation of a new space (such as learning centers), and especially today's reclaiming of on-campus education continues the history of the university. Not the history of the university as an institution or an idea, but the history of the university as it originated in medieval times in local and particular movements called universitas studii, that is, localized gatherings of students. ${ }^{3}$ There are many ways to study, but university study is a particular form of study. One that has its own history and find its origin in a particular gathering of people declaring: "We are not pupils, nor disciples, nor apprentices, but

1 Daejin Kim, Sheila Bosch, and Jae-Hwa Lee, "Alone with Others: Understanding Physical Environmental Needs of Students within an Academic Library Setting," The Journal of Academic Librarianship, no. 46 (2020). https://doi.org/10.1016/j. acalib.2019.102098.

2 Jairo Jimenez, Studying as Wayfaring. Looking at Contemporary Study Practices in the University (KU Leuven: Unpublished PhD-thesis, 2019).

3 Jacques Verger, "Patterns," in A History of the University in Europe. Volume I: Universities in the Middle Ages, ed. Hilde De Ridder-Symoens (Cambridge: Cambridge University Press, 1992), 35-72. 
students." ${ }^{4}$ Back then, this declaration manifested a (de)identification with practices of initiation and socialization into particular social, cultural, vocational or religious groups. The gathering as students constituted new public pedagogic forms (such as the lecture and the disputatio), outside the seclusion of the monastery or the workshop of professional guilds. ${ }^{5}$ The emergence of these gatherings implied the profanation of the sacred scripture that became available as (or was transformed into) a book to study through what Marin calls a "mediatic displacement." That is, the Holy Scripture transformed from a "message" that could be heard, recalled, and obeyed into what could be read and seen together, publicly as a "book-text." is turned into a text means that it becomes a study object or a thing that can be notated and annotated; not just reproduced or recollected. ${ }^{8}$ It becomes a thing that can be studied and interrogated, publicly and collectively, not just copied and obeyed.

The university and its public pedagogic forms have been reinvented throughout the course of history. A history that could be conceived as a history of profanations (in the sense of setting something free for public use) and of (de)identifications. ${ }^{9}$ For instance, one could point to students at the end of the 18th-century declaring: "We are no state officials, no civil servants, nor clergyman or appointed teachers, but students and scholars." Here, the universitas studii, constituted a de-identification with practices of cultivation, preparation, and training of citizens and servants for the nation state or for

4 Jan Masschelein and Maarten Simons, "Universitas Magistrorum et Scholarium: A Short History of Profanation," in Curating the European University. Exposition and Public Debate, eds. Maarten Simons, Mathias Decuypere, Joris Vlieghe, and Jan Masschelein (Leuven: Leuven University Press, 2011), 81-88.

5 Stephen Ferruolo, The Origins of the University. The Schools of Paris and Their Critics (Stanford: Stanford University Press, 1985).

6 Mediatic displacement being "a media configuration which manages to cancel the effect of one medium by using another one against it, and, in a series of transcoding movements, to enact educational suspension of the world." Lavinia Marin, On the Possibility of a Digital University. Thinking and Mediatic Displacement at the University (Cham: Springer, 2021), 29.

7 Ivan Illich, In the Mirror of the Past. Lectures and Addresses 1978-1990 (New York: Marion Boyars, 1992).

8 Mary Carruthers, The Book of Memory. A Study of Memory in Medieval Culture (Cambridge: Cambridge University Press, 2008).

9 We only want to give here some very limited indication of a possible history of the university from a pedagogical perspective that starts from the forms of study and of coming together as students that have come to life under that name. Masschelein and Simons, "Universitas Magistrorum et Scholarium". 
the church. It constituted new public pedagogic forms (such as the seminar), new ways of gathering as students that transcended the "domestic" gatherings (as Kant called them) of state and church. These pedagogic forms implied the profanation of reason; liberating reason from domestication, and appropriation in operations of private use and addressing anyone-anyone who was not lazy or a coward - as capable of reason in its public use. ${ }^{10}$ Another example we can point to is the movement of May 1968 where the university was reinvented once more as a public pedagogic form by people gathering and declaring: "We are no generation waiting to be cultivated, no modern subject of a particular culture, but students."

We contend that the physical (re)discovery and (re)occupation of the university since the turn of the century-even if it is one that is rather noiseless, less spectacular, and uproarious than 68 - continues the history of smaller or bigger revolutionary movements establishing a universitas studii. The thesis that we will formulate is, first, that the de-identification with screen work and the affirmation of the importance of places to study, is about the affirmation of the importance of the students' "attendance" (and attention) in order to realize a public and collective "presence-of-mind." Second, we elaborate on the thesis that students today perhaps are not re-discovering on campus education in order to fulfill their need for social life or social contact while being turned into isolated learners, but to answer the call of the university and its promise of a meaningful, contestable, experimental encounter with "something" that makes them study and engage in truth-finding/speaking. It is about reattachment, localization, and dependency. Perhaps this reattachment is also what motivates the unexpected longing for what some have called outdated, ineffective educational gatherings, such as the lecture. These gatherings seem to provide and require a mediatic and bodily displacement that the screen (alone) does not provide nor require. To be more precise, we do not contend that access to the Internet (and its constantly increasing audio-visual archive) and to digital communication (through the interface of the screen) are making study impossible. On the contrary, we think they are to become an essential opportunity. However, such access is not enough to provide the conditions for study (there is need for new practices, protocols, and requirements) and, to the extent that this access operates as an apparatus instead of a tool, may potentially impede them.

10 Immanuel Kant, "An Answer to the Question: 'What Is Enlightenment?', ' in Kant's Political Writings, ed. Hans Reiss, trans. Hugh Nisbet (Cambridge: Cambridge University Press, 1977), 54-60.

11 Bill Readings, The University in Ruins (Cambridge: Harvard University Press, 1996). 


\section{"We Are No Screenworkers (In the Clouds), But Students (In the Presence Of)"}

During the past decades, university life and work has increasingly become digital. The COVID-19 pandemic gave a strong impetus to this development with universities going massively, and often completely, online. It implies that we-as students, but also as professors-have become screen workers, or at least have experienced what it would be like to work (exclusively) with and through a screen and its steering software. ${ }^{12}$ This "screenification" means that everything becomes a matter of communication of information, and whereby all information is passing through technical images produced by apparatuses. ${ }^{13}$ An apparatus, according to Flusser, is not a tool that can be used as an instrument, but is a programmed device that needs functionaries to operate. For that reason, the student and professor as screen worker is a functionary: whatever he or she does online is a function in a programmed reality. In a similar way, "screen learning" increasingly comes down to performing functions (learning activities) in a programmed learning environment. ${ }^{14}$

For the screen worker, everything that matters is enclosed as a package of information, and is something to be unpacked, recorded, copied, pasted, saved, deleted, recovered, but also what can be reworked, overwritten, uploaded, and downloaded. The key activity - that is, the activity that adds value-is receiving and sending information (i.e., adding information to information) with the ideal situation to have fully transparent communication of pure information. The key mental state for the screen worker who is a functionary of digital apparatuses is "availability": being available to the apparatus in order to send and receive messages. It is not by accident, then, that online meetings often are about passing in turn information enclosed in messages. The online apparatuses have difficulty making time and space for (studious) conversation and, as a consequence, for something (of concern) being created throughout the conversation. In a similar way, talking with students online becomes an exchange of information wherein what happens is more about passing commentaries to make what they want to say transparent than actually engaging with what they have to say. The mailbox and several (learning)

12 This 'screenification' can, of course, be related to other developments affecting the university such as the (post-)fordification of academic work.

13 Gerd Leonhard, Technology vs. Humanity. The Coming Clash Between Man and Machine (Independently published, 2016).

14 Vilém Flusser, Into the Universe of Technical Images (Minneapolis: University of Minnesota Press, 2011). 
platforms make up the desk of the screen worker; a programmed environment of messages waiting to be processed through performing the meanwhile typical functions that add information on information such as replying, sending, attaching, screening, reviewing, uploading, zooming, copying/pasting...

As far as we have become screen workers and learners, we perhaps have tried and savored a truly angelic existence. We might have tasted what it means to live as a pure messenger-with the figure of the angel as the bringer of messages. ${ }^{15}$ And perhaps we have experienced what it would mean to live in the cloud - free of gravity and weight. However, while focusing on what happens online, we often forget about the kind of bodily life that is required to sit in front of a screen and to be online. This is not a life without a body (we are probably more aware of this now than ever), but with the body entering a sphere where all attachments are suspended and where the body becomes a provider of energy for communicating information, performing functions, and being available. The screen worker's body is transformed into a kind of living battery that operates as the prosthesis of digital communication apparatuses. The screen worker knows very well that the bodily battery also has to be recharged - or this is at least the often repeated message of health care workers.

When students de-identify themselves with the figure of the screen worker and learner, they seem to indicate that what is required to perform functions in digital apparatuses no longer allows for study. But what is studying? A crucial element of what is at stake in studying becomes clear when comparing reading a novel with studying that novel. Reading a novel implies a particular kind of absorption, being carried away by the narrative and by following the message. Studying the novel implies a mediatic displacement where the novel is transformed into a text that can be talked about, annotated, read aloud, and discussed. In studying, the novel is transformed into a thing. That is, the novel becomes something that makes us think. In order for that to happen, studying requires a displacement that allows for taking a distance (a step back) in view of re-establishing a new relation (becoming attentive). A "trans-substantiation" through new media (e.g., written notes, oral comments) is required to place the novel at a distance and in order for it to become a thing to talk or write about, or even just to look at as an artefact. Angelic screen work, and the condition of being a functionary, does not—at least not easily or "naturally" - allow for that displacement. The interface of the screen facilitates the passing of information and enables efficient communication. But,

15 Michel Serres, La Légende des Anges. Hermès, Gabriel, Turing (Paris: Le Pommier, 2016). 
absorbed in screen communication, there is often little occasion for something to become a "thing" and to make us think.

Hence, we understand becoming a student as being confronted with something that gains the force to make us think. This can be a novel, but also a virus or social phenomenon. And for that to happen, what is needed is a kind of de-automatization. The difference between reading and studying is helpful again. Reading a novel is a kind of automatism. Of course, during reading, ideas can come to mind. But when carried away by those ideas, it interrupts the reading. Studying requires a de-automatization of reading, but also of looking, listening, and feeling. For that, a countermovement is needed. It requires effort, concentration, discipline, and method. ${ }^{16}$ It requires a particular kind of work to be done. It is about actively resisting the urge to lose yourself in the novel or in your observations of social and physical life. What this countermovement makes possible is what could be referred to as presence of mind. Someone without presence of mind is someone whose thoughts are carried away, who is absent, or who lives in another world. And this absence of mind is often the condition of the screen worker who-by definitionhas to perform programmed and automated functions. As a functionary, the screen worker lives, so to speak, permanently absorbed in the here and now. Not "presence of mind," but being "up-to-date," is a major concern for this form of work. Any displacement would interrupt the programmed chain of messages.

The presence of mind while studying means being somewhere where something can present itself and starts - in the strong sense- "objecting." It is not that the novel becomes an object of knowledge waiting to be known. Studying takes place before knowing. When something starts to object to taken for granted ways of speaking and looking it calls our attention and makes us think (again). This state of mind comes close to what Agamben discusses in terms of "contemporariness": "a singular relationship with one's own time, which adheres to it and, at the same time, keeps a distance from it." 17 When students re-discover the university today, in the age of COVID 19 , they may not only rediscover the importance of a presence of mind while studying, but also the university as a specific place embodying (even in its architecture) the effort, concentration, discipline, and method needed for a presence of mind. This seems to be the "pressure" they find in libraries, for

16 Fernando Barcéna, Jorge Larrosa, and Maximiliano Lopez, eds., Elogio del Estudio (Buenos Aires: Miňo y Dávilla, 2020).

17 Giorgio Agamben, What Is an Apparatus and Other Essays (Stanford: Stanford University Press, 2009), 41. 
instance; a concentration of energy that helps to resist the call for availability of the digital apparatuses, breaks the forces of automation, and suspends the small pleasures of one's life as a functionary. The university in that sense is an artificial place that attempts to resist automation in speaking, looking, listening, and feeling. University places are real places in between or "milieus" where presence of mind in the midst of things can become possible.

\section{"We Are No Independent Learners, But Dependent Students”}

The digital apparatuses allow “(...) all individuals to learn, anywhere, anytime, through any device, with the support of anyone." 18 This was once a policy objective that was being gradually implemented; however, it has been quickly realized out of necessity due to the COVID 19 crisis. Learning has become increasingly personalized, and students are becoming independent from institutionalized forms of education; including common curricula, standardized timetables, and fixed study programs. This liberation of the student and the student becoming an independent learner is only possible when learning is transformed largely into screen work. The student pays a price for this personalization and independence: the call (not the order) to act as a functionary of apparatuses and to find over and over again all energy or force in himself/ herself to perform functions in a programmed and automatized digital environment, and as a consequence the risks of being absorbed by and isolated with their screens at home (and as creating their home).

Today students seem to find the price too high. The price for their independence seems to be the reduction of the potential for study itself. They seek to escape their homes and reclaim education on campus. Not only to see their friends or socialize, but because they actually want "to be there." They seem to want to attend and be present in the lectures and seminars, including the meetings and conversations during breaks, or on leaving or entering the lecture halls and seminar rooms. It seems as if they are seduced by the promise of an encounter and re-call or re-discover the force and energy that is generated when going to class and collectively attending a lecture or seminar. A force and energy that is very different from the force that a student has to generate for oneself at home in order to sit behind the screen and perform

18 European Commission, Opening up Education: Innovative Teaching and Learning for All through New Technologies and Open Educational Resources. Communication from the Commission (COM (2013) 654 final) (Brussels: European Commission), 3. 
functions. The movement of leaving one's home has been a key element of the origin of the university ${ }^{19}$; it was about placing and keeping the house(hold)but also the houses of God such as churches and cathedral schools-at a distance, in order to arrive in a specific energetic and forceful milieu. It is the exact opposite of current arguments in favor of distance education and home delivery of university education which in fact increases, above all, the required forces and energy by each student to make operate the apparatuses on which the delivery relies.

Students seem to rediscover today that they are dependent on a milieu that creates the force and energy that allows for a presence of mind and to encounter an object of study. This encounter requires multidimensionality, not only multisensoriality, in order to constitute a milieu, a middle or in-between where things can be seen-so to speak-from all sides. According to Flusser, what the screen interface does when operating as an apparatus of calculation is reducing everyone and everything to zero dimensions. Although the screen allows one to "see" something in more dimensions, what is projected are technical images generated by code that in itself does not have any dimension. What is on screen can be closed, clicked away, or deleted at any time. ${ }^{20}$ And perhaps this lack of dimensions is what students today are confronted with, and what makes them rediscover the importance of the dependence on forces of a multi-dimensional place where something gains the force to make them think. To become a university student, one is dependent on the condition of being contradicted, of being talked-back-to, and of having an object of study that speaks back to one. But also, on others that partake, add, question. Others with their bodies, smells, murmur, and rustling clothing offer the "parure" ${ }^{21}$ of the gathering that contributes to disposing or releasing the knowledge from its weight as pure statement/information by making it into a speech-act; something that is actually said by some-body/thing.

The multidimensional milieu of university thinking also implies that it is always a form of collective and public thinking, and that the student's presence of mind is collective and public. Thoughts and ideas are brought into an exchange, they are textualized or visualized, hence become available, open for public use, and thus also localized in order to be used. The becoming public of something is exactly what requires a presence of mind of students, and this

19 Verger, "Patterns," 41.

20 Flusser, Into the Universe of Technical Images.

21 Roland Barthes, "Au séminaire," in Le Bruissement de la Langue. Essais Critiques IV (Paris: Éditions du Seuil, 1984), 393-404. 
is what makes that students themselves are always also becoming public. The milieu of the university makes what they (start) to say about things, the truth claims they make, as well as their hesitations when new things start to object is not just a matter of opinion, but a public articulation of thinking that is provoked and should be discussed in terms of truth(fullness). The communication of the student is never a dialogue, but a form of public thinking, speaking, and writing where there is always "a third" involved. This is what students are able to encounter during a seminar, lecture, or in a laboratory. If studying indeed involves a collective and public presence of mind, it might also help to understand why students want to be part of the milieu of the seminar, lecture, or laboratory. They seem to prefer to be where something happens and as it happens, despite the streaming or recordings being available. The mediation by the screen transforms the lecture, seminar, or discussion into an image, which then reduces the dimensions and the related forces, and makes the student an outsider or spectator. Studying seems to not only involve a presence of mind but a simultaneous presence of body.

The university, then, would not be a "platform" where thoughts take-off or are launched, but, the other way around, a place where they can land and become embodied. The auditorium is no church where our thoughts ascend to heaven, but the place where we want those thoughts can land. This allows digital angels to descend from the cloud to become a student; someone who is exposed and can become affected, and not only informed by a "messenger." The university student cannot be an angel separate from their body and without attachments, without friction. Studying is about presence of mind and body when thoughts land (or try to land) and become "matter." Matter of thought.

\section{On Revolution}

The question "What is studying?" was proposed by the initiators of this special issue with an explicit reference to the question that Kant responded to in his famous essay "What is Enlightenment?". In concluding our response, we want to take up Foucault's reading of Kant's essay as a way in which Kant poses the question of "actuality": What happens today? Kant, according to Foucault, tries to show how a certain element in the present is the carrier and sign of a process that concerns $u s$ and our thinking. ${ }^{22}$ In his text on the university, The conflict of the faculties, Kant, in this sense, points to the French

22 Michel Foucault, "What Is Enlightenment?" in The Foucault Reader, ed. Paul Rabinow (New York: Pantheon, 1984), 32-50. 
Revolution and finds in it a sign of existence of the progress of humanity. ${ }^{23}$ And now, we suggest to make an analogy here and discern or detect an enthusiasm in the occupation of libraries by students, the constructions of new spaces and especially in the reclamation of on campus education. We interpret this enthusiasm as a sign that the university continues to exist and to manifest itself.

In addition, the university manifests itself as a pedagogical phenomenon. We hear and read today that students - who are now, in the times of the pandemic, more than ever isolated and closed up with their screens as "interface" to take part in the online university — are feeling lonely and are longing for social connection as a remedy against their digital solitude. However, even if going to the university allows students to discover who they are among others who do not know them and provides the joy of (new) social contact, we do not think that it is the "social dimension" as such that arouses the longing for being "on campus" because it would offer the occasion for (embodied) social relations and talks (in-between and besides the study gatherings), which would provide balance juxtaposed with the isolated screen work at home. It is not only a longing for the idealized "past" or to be caught by "campus-envy". ${ }^{24}$ Students also long to be present in lectures, seminars, excursions, and exercises "on campus." Hence, we think that these des-identifications, these declarations (we are not just home-screen-workers, nor just independent learners), are not, and perhaps never were, simply reclaiming or mourning the university as a mainly social phenomenon. The transition to online learning is not ending the university forever since it would end it also as a social phenomenon, as Agamben commented, hence being also "the end of being a student ... as a form of life." ${ }^{25}$ We take the occupation, the construction, and specially also the reclamation of education on campus precisely as part of the revolutionary movement that establishes an universitas studii, as the signs that the university takes place again as a pedagogical phenomenon. It takes place as a distancing from the home; it is not only about an expanding or renewal of the social—which is, for sure, also an issue-but also about

23 Immanuel Kant, "The Conflict of the Faculties," in Religion and Rational Theology, ed. and trans. Allen Wood and George di Giovanni (Cambridge: Cambridge University Press, 1996).

24 Siân Bayne, Peter Evans, Rory Ewins, Jeremy Knox, James Lamb, Hamish Macleod, Clara O'Shea, Jenn Ross, Philippa Sheail, and Christine Sinclair, The Manifesto for Teaching Online (Cambridge: The MIT Press, 2020).

25 Giorgio Agamben, "Requiem for the Students," trans. Alan Dean. May 2020. Retrieved from https://d-dean.medium.com/requiem-for-the-students-giorgioagamben-866670 cl1642. 
a profanation of the social, rather than its (re)sacralization, and a liberation from being absorbed by the screen.

Declaring not to be independent screen workers, but students and professors is not at all about rejecting the use of digital media and declining online activities. They cannot be but fully part of the university campus. But it is to suspend the (automatic) operations of the screens and the apparatuses through which they operate as well as the mobilized forces within students that turn us into functionaries. Foremost, the ambition is to look for practices that transform screens and other digital media into tools for study. Or, to put it a bit provocatively, to purely instrumentalize them to allow for study and to help us to be/become students again.

\section{Bibliography}

Agamben, Giorgio. What Is an Apparatus and Other Essays. Stanford: Stanford University Press, 2009.

Agamben, Giorgio. "Requiem for the Students." Translated by Alan Dean. May 2020. Retrieved from https://d-dean.medium.com/requiem-for-the-students-giorgio-agamben-866670cl1642.

Barcéna, Fernando, Jorge Larrosa, and Maximiliano Lopez, eds. Elogio del Estudio. Buenos Aires: Mi囚o y Dávilla, 2020.

Barthes, Roland. "Au séminaire." In Le Bruissement de la Langue. Essais Critiques IV, 393-404. Paris: Éditions du Seuil, 1984. (Original essay published 1974).

Bayne, Siân, Peter Evans, Rory Ewins, Jeremy Knox, James Lamb, Hamish Macleod, Clara O'Shea, Jenn Ross, Philippa Sheail, and Christine Sinclair. The Manifesto for Teaching Online. Cambridge: The MIT Press, 2020.

Carruthers, Mary. The Book of Memory. A Study of Memory in Medieval Culture (Second edition). Cambridge: Cambridge University Press, 2008.

European Commission. 2013. Opening up Education: Innovative Teaching and Learning for All through New Technologies and Open Educational Resources. Communication from the Commission (COM (2013) 654 final). Brussels: European Commission.

Ferruolo, Stephen. The Origins of the University. The Schools of Paris and Their Critics. Stanford: Stanford University Press, 1985.

Flusser, Vilém. Into the Universe of Technical Images. Minneapolis: University of Minnesota Press, 2011.

Foucault, Michel. "What Is Enlightenment?" In The Foucault Reader, edited by Paul Rabinow, 32-50. New York: Pantheon, 1984.

Illich, Ivan. In the Mirror of the Past. Lectures and Addresses 1978-1990. New York: Marion Boyars, 1992.

Jimenez, Jairo. Studying as Wayfaring. Looking at Contemporary Study Practices in the University. KU Leuven: Unpublished PhD-thesis, 2019. 
Kant, Immanuel. "An Answer to the Question: 'What Is Enlightenment?', In Kant's Political Writings, edited by Hans Reiss, translated by Hugh Nisbet, 54-60. Cambridge: Cambridge University Press, 1977. (Original essay published 1784).

Kant, Immanuel. "The Conflict of the Faculties." In Religion and Rational Theology, edited and translated by Allen Wood and George di Giovanni. Cambridge: Cambridge University Press, 1996. (Original essay published 1798).

Kim, Daejin, Sheila Bosch, and Jae-Hwa Lee. "Alone with Others: Understanding Physical Environmental Needs of Students Within an Academic Library Setting." The Journal of Academic Librarianship, no. 46 (2020). https://doi.org/10.1016/j. acalib.2019.102098

Leonhard, Gerd. Technology vs. Humanity. The Coming Clash Between Man and Machine. Independently published, 2016.

Marin, Lavinia. On the Possibility of a Digital University. Thinking and Mediatic Displacement at the University. Cham: Springer, 2021.

Masschelein, Jan, and Maarten Simons. "Universitas Magistrorum et Scholarium: A Short History of Profanation," In Curating the European University. Exposition and Public Debate, edited by Maarten Simons, Mathias Decuypere, Joris Vlieghe, and Jan Masschelein, 81-88. Leuven: Leuven University Press, 2011.

Readings, Bill. The University in Ruins. Cambridge: Harvard University Press, 1996.

Schildermans, Hans. Making a University. Introductory Notes on an Ecology of Study Practices. KU Leuven: Unpublished PhD-thesis, 2019.

Serres, Michel. La Légende des Anges. Hermès, Gabriel, Turing. Paris: Le Pommier, 2016. Verger, Jacques. "Patterns." In A History of the University in Europe. Volume I: Universities in the Middle Ages, edited by Hilde De Ridder-Symoens, 35-72. Cambridge, Cambridge University Press, 1992. 
